\title{
The Threatened Constitutionalization of the Internal Affairs Doctrine in Corporation Law
}

\author{
Richard M. Buxbaum
}

The social stress attendant on the recent merger, takeover, and buyout wave understandably has led to state efforts to impose some regulatory controls on these corporate processes and, in turn, to federal efforts to control the state regulatory developments. ${ }^{1}$ The Supreme Court's 1982 decision in Edgar v. MITE Corp. ${ }^{2}$ signalled a shift of direction in federal judicial scrutiny of state regulatory efforts. That decision moved away from the potentially preemptive effects of the Williams Act under supremacy clause principles and towards the less controllable and more freewheeling use of dormant commerce clause doctrine. The particular use or misuse of traditional commerce clause balancing tests in that case can be criticized; ${ }^{3}$ in addition, some courts since 1982 reverted to a Williams Act preemption argnment ${ }^{4}$ despite its failure to coinmand a Supreme Court majority in Edgar. Most courts, however, used the

$\dagger$ Professor of Law, Boalt Hail School of Law, University of California, Berkeley. A.B. 1950, LL.B. 1952, Cornell University; LL.M. 1953, University of California, Berkeley.

1. Although federal efforts to control state regulation have primarily involved the federal judiciary, there also has been some federal administrative involvenent. For example, in its decision to prohibit selective issuer tender offers, Equal Treatment of Security Holders, 51 Fed. Reg. 25,882 (1986) (to be codified at 17 C.F.R. 240.14d-10), the SEC specifically discussed the preemptive effects of its regulation on state laws. See Tender Offer Amendments, Securities Act Release No. 6653, Fed. Sec. L. Rep. (CCH) 84,016, at 88, 191-92 (July 11, 1986). On this question of the effects of federal administrative action, as contrasted with federal legislation under the supremacy clause, see Foote, Administrative Preemption: An Experiment in Regulatory Federalism, 70 VA. L. REV. 1429 (1984).

2. 457 U.S. 624 (1982).

3. See Buxbanm, Federalism and Company Law, 82 Mich. L. Rev. 1163, 1173-80 (1984) [hereinafter Buxbaum, Federalism]; Buxbaum, Federal Aspects of Corporate Law and Economic Theory in Contract and Organisation 274 (T. Daintith \& G. Teubner, eds., Berlin 1986) [hereinafter Buxbaum, Federal Aspects]. For more general discussion of the proper approach to the so-called balancing test, see Regan, The Supreme Court and State Protectionism: Making Sense of the Dormant Commerce Clause, 84 Мich. L. REv. 1091, $1278-87$ (1986); see also Smith, State Discriminations Against Interstate Commerce, 74 CALIF. L. REv. 1203 (1986) (identifying discrininations against interstate conmerce, rather than amorphous balancing, as the touchstone of dornant commerce clause analysis.)

4. See Dynamics Corp. of America v. CTS Corp., 794 F.2d 250, 260-63 (7th Cir. 1986), rev'd, 55 U.S.L.W. 4478 (U.S. Apr. 21, 1987) (Nos. 86-71 \& 86-97); Martin Marietta Corp. v. Bendix Corp., 690 F.2d 558 (6th Cir. 1982); cf. Data Probe Acquisition Corp. v. Datatab, Inc., 568 F. Supp. 1538, 1553-55 (S.D.N.Y.), rev'd, 722 F.2d 1 (2d Cir. 1983), cert. denied, 465 U.S. 1052 (1984) (extending Williams Act preemptive reach to prohibit target management defense authorized under state law). 
dormant cominerce clause as the major testing device against which the so-called second-generation state takeover statutes are to be judged. ${ }^{5}$

The second-generation statutes, while not all cut froin the saine cloth, display some common characteristics deriving from their coinunon effort to survive federal scrutiny. Unlike their substantively mandatory predecessors, they tend to be directly or indirectly permissive. That is, they require a shareholders' decision either to keep the firm outside the statutory regime and thus "in play" for takeover possibilities or to take the firm "out of play" by an affirmative decision to that end. ${ }^{6}$

In CTS Corp. v. Dynamics Corp. of America, ${ }^{7}$ the Supreme Court has laid down significant new guidelmes and constraints for these secondgeneration state takeover statutes. It reviewed a typical one, the Indiana Control Share Acquisitions Chapter of the Indiana Business Corporation Law, ${ }^{8}$ under both Williams Act-based preemption and dormant commerce clause principles. The Court validated the statute against both challenges. The statute, whose jurisdictional reach is discussed below, ${ }^{9}$ is applicable unless the corporation's sliareholders opt out of its purview (before August 1, 1987 this is structured as an opt-in decision of the board of directors). A person acquiring "control [common] shares" (nore than twenty percent initially or at step-ups to one-third or one-half froin prior platforms) does not get to vote them, unless a majority of "disinterested" shareholders pass a special resolution to that effect. A special ineeting for this purpose, held within fifty days of acquisition, can be deinanded by the acquiror, and certain redemption arrangements are available, at the option of the corporation, if the enabling resolution fails to pass.

After reading the statute in a way that implies that at least the potentially tendering shareholders, if not the bidder itself, can vote the actually or potentially tendered shares at that meeting, the opinion, only

5. See, eg., Dynamics Corp., 794 F.2d at 263-64; Fleet Aerospace Corp. v. Holderman, 796 F.2d 135, 139 (6th Cir. 1986) remanded sub nom. Ohio v. Fleet Aerospace Corp., 55 U.S.L.W. 3724 (U.S. Apr. 28, 1987) (No. 85-344) in light of CTS. For other cases that employ a commerce clause analysis but come to a different result, see L.P. Acquisition Co. v. Tyson, 772 F.2d 201, 205-07 (6th Cir. 1985) (per curiam) (state statute does not violate commerce clause); Cardiff Acquisitions, Inc. v. Hatch, 751 F.2d 906, 909-12 (8th Cir. 1984) (same). For a recent review of the lower courts' varying treatment of the problem, see Danilow \& Bentley, State Takeover Statutes After Mite, 20 REV. SEC. \& COMMODITIES REG. 13 (1987).

6. Most of these second-generation statutes permit corporations, subject to their prescriptive jurisdiction, to opt into or out of "fair price" requirements, which are designed to require offerors who have gained control through a first bid to offer the same or a formulaic (higher) price to thc remaining independent shareholders in the case of a full merger. For a review of these statutes, including the element of permissiveness, see Romano, The Political Economy of Takeover Statutes, 73 VA. L. REV. 111, 116-20 (1987).

7. 55 U.S.L.W. 4478 (U.S. Apr. 21, 1987) (Nos. 86-71 \& 86-97).

8. IND. CODE $\S 23-1-42-1$ to 23-1-42-11 (Supp. 1986).

9. See infra text following note 14 . 
arguendo accepting that a preemption test might be appropriate, passed the statute under that test. The critical comment, placed in a footnote, is that as interpreted, the statute unlike the Illinois law invalidated in Edgar v. MITE, did not tilt the level playing field between bidder and target management, but functioned only "to grant shareholders the power to deliberate collectively about the merits of tender offers." 10 The Court separately and closely examined the delay inherent in consummation of tender offers until after the enfranchising vote; discussed and inferentially authorized contingent tender offers, to relax bidder inhibitions; and pointed out that a successful attack on this statute would slide down the slippery slope of condemning all mamier of innocuous state laws like those allowing staggered boards or cumulative voting simce these, too, have some delaying effect on control transactions.

This part of the opinion creates an opening, albeit a narrow one, under Williams Act preemption scrutiny for various types of state regulation. Whether the preemption bar will come down on statutes equally voluntary but authorizing a different constraint sucl as a "fair price put" for remaining shareholders, ${ }^{11}$ or substantively like Indiana's but mandatory, is not clear.

Nor is it clear whetlier the decision has rejected the problematical "contractarian" analysis some courts have used, ${ }^{12}$ Shelley v. Kraemer ${ }^{13}$ notwithstanding, to prevent the particular transaction effected under a general corporation law code (not targeting control transactions specifically) from being characterized as "state action," and thus to render it categorically unassailable under preemption and perhaps under dormant commerce clause analyses. By focusing instead on the modest substance and voluntary application of the Indiana provision, the Court may have signalled the rejection of this alternative approach, an approach that in any event is rather arbitrary to the extent it distinguishes identical corporate action depending on whether it is taken under general or special statutory authorization. ${ }^{14}$

The second-generation statutes, unlike their jurisdictionally more expansive predecessors, also tend to apply only to firms incorporated locally or at least to firms with predommant ties of ownership, facilities, payroll, and sales to the prescribing jurisdiction. This limited jurisdictional reach now turns out to be critical to the fate of these statutes under

10. 55 U.S.L.W, at 4481 n.7

11. See, e.g., N.Y. BUS. CORP. LAW $\S 912$ (McKinney 1986). Note that the Indiana statute also includes this feature. See IND. CODE \& 23-1-42-11 (Supp. 1986).

12. See Data Probe Acquisition Corp., 722 F.2d at 5; Moran v. Household Int'1, Inc., 500 A.2d 1346, 1353 (Del. 1985).

13. 334 U.S. 1 (1948).

14. Cf. Romano, supra note 6 , at 113 (asking why statutes are needed since current law allows "self-help" emplacement of defenses). 
dormant commerce clause scrutiny. The decision involving a typical statute, applicable only to locally incorporated companies, at first glance may seem to have brouglit some guidance to this unsettled area of the law. The evolving jurisprudence undoubtedly will not be limited to one further, even authoritative decision, however, for two further reasons that need brief review.

First of all, the pressure on state legislatures to "do something" about some of the social consequences of corporate takeovers, buyouts, and mergers will not abate soon or easily. Whether spurred by powerful local enterprises, worker concerns, communities worried about the "disappearing" local headquarters, or even by generalized social concerns, these pressures are as unavoidable as they are legitimate. A federal regime that relies solely on "the market" to regulate these structural phenomena is cold comfort to local political umits called upon to bear the costs of economic change today while the greater benefits of tomorrow manifest themselves elsewhere. ${ }^{15}$

In the second place, these second-generation statutes already doand the third and $n$-generations statutes, spurred on by this very case, undoubtedly will-approach the takeover problem not from the "outside," via direct regulatory scrutimy, but rather from the "inside," via substantive changes im traditional rules governing the internal affairs of corporations. Federal doctrine, on the other hand, defines federal regulation of state corporation law-whether by federal securities laws or by dormant commerce clause review-as limited to regulation of the securities markets aspect of company activity. Moreover, federal doctrine, whicl $C T S$ further supports, holds this latter aspect to be entirely distinct from regulation of a company's internal affairs-that is, the relation among owners, and the relation between owners and managers and the entity. ${ }^{16}$ These internal relations are the province of the states to govern.

The court of appeals in CTS, followimg an offhand footnote in Edgar v. MITE, trivialized this distinction, and asserted that state regulation of the transfer of shares intrudes on a market function and thus cannot hide from federal scrutimy among the activities immunized as "internal affairs." 17 The dubious nature of this distinction should be apparent from recollecting the traditional treatment of stock transfer restrictions and of mergers, ${ }^{18}$ and indeed the Supreine Court in CTS decided that the distinction does not suffice to sweep away the substantively milder ver-

15. See Stewart, Pyramids of Sacrifice? Problems of Federalism in Mandating State Implementation of National Environmental Policy, 86 YALE L.J. 1196 (1977).

16. See Santa Fe Indus. v. Green, 430 U.S. 462, $477-80$ (1977).

17. Dynamics Corp. of America, 794 F.2d at 264.

18. Buxbaum, Federalism, supra note 3, at 1172; see Coffee, Shareholders Versus Managers. The Strain in the Corporate Webb, 85 MicH. L. REv. 1 (1986). 
sions of today's second-generation statutes. Most likely it will not suffice even if more sophisticated and substantively robust versions of these statutes become necessary and crop up as a third generation.

The jurisdictional side of this state effort also is evolving, however, and may in time take on as much importance in federal constitutional analysis as the substantive aspect. The first-generation statutes indeed were jurisdictionally exorbitant-the Illinois act invalidated in Edgar $v$. $M I T E$ apphed to any corporation with at least ten percent of a target class of shareholders or ten percent of its stated capital and paid-in surplus represented im the state-but many of the second-generation statutes may be dysfunctionally and uimecessarily diffident in their jurisdictional claims. For example, the Indiana statute that was at issue in CTS only apphes to firms incorporated in Indiana. Since corporations can easily avoid the reach of the statute by incorporating elsewhere, the Supreme Court's conclusion that invalidation of the statute under the dormant commerce clause was overkill by the court of appeals is understandable. ${ }^{19}$ This himited jurisdiction, however, may soon be seen as an madequacy of these new statutes. There is a large middle area between the jurisdictional reach of the Illinois and Indiana statutes. The recent renewed migration of essentially local (though publicly held) corporations to Delaware ${ }^{20}$ in order to gain the benefit of the recent statutory treatment of director liability ${ }^{21}$ may hasten the mevitable return of the jurisdictional pendulum at least to a position capturing the so-called "pseudo-foreign" corporation under the corporation law of its true home state.

The extension of sophisticated stock-trading market systems to cover a cohort of smaller firms with fewer shareholders-exemplified in the NASDAQ National Market System-will not stem this pressure for "home state" regulation of corporations (including takeover regulation). Since protecting local investors is not the sole impetus for state regulation, the protection available from access to more or less public markets is by definition an incomplete answer to state concerns. In addition, some elements of public investor protection have been placed back into the lap of the states as a result of the erosion of certain traditional norms of investor protection heretofore found in exchange histing requirements.

19. See Buxbaum, Federal Aspects, supra note 3 at 263-64. Compare the "public choice" argument of Winter, Private Goals and Competition Among State Legal Systems, 6 HARV. J.L. \& PuB. PoL'y 127 (1982).

20. An informal inquiry disclosed that roughly 20,000 merger documents have been received by the Delaware Secretary of State for filing. Even assuming that some (10\%?) involve actual rather than shell reincorporation mergers, this is still a startling volume.

21. DeL. Code ANN. tit. 8, § 102(b)(7) (Supp. 1986). For other states' responses, see Hanks, State Legislative Responses to the Director Liability Crisis, 20 REv. SEC. \& CoM. REG. 23 (Feb. 11, 1987). 
This erosion, exemplified by the controversy over the introduction of essentially nonvoting common stock, ${ }^{22}$ becomes especially significant to the extent federal authorities propose that any new regulation of these matters be left to the states as traditional "internal affairs."

It thus seems that we soon may have a moderate amount of interstate conflict regarding substantive regulation of these structural changes. This will be particularly true if Delaware, for understandable reasons, were to eschew these types of controls in favor of continuing to place decisional authority with respect to structural changes in the hands of the board of directors. We also soon may have a somewhat more differentiated palette of takeover-related responses, with stronger ones (such as dual-class common stock) subject to the decision of shareholders and milder ones (such as moderate fair-price or "dissenters" appraisal rights) applicable on a mandatory, or at least on a director-triggered, basis. In other words, to the classic collisions liandled by cominerce clause and supremacy clause analysis, which are simply vertical conflicts between state and federal regimes, horizontal collisions or at least incongruities among the states will be added: the contending claims of the law of the state of incorporation and the law of moderately assertive "Irone" states.

This rivalry will be sliarpened as the internal affairs doctrine itself undergoes the moderate expansion already adumbrated in CTS. The new statutes of the Indiana sort take a collective ratler than individualistic approacl to the very concept of stock ownership and to its alienability and restrictability. Indeed, these statutes can only fulfill their purpose to the degree they do so. Ordmarily, only entity-related structural decisions-statutory mergers or sales of assets and statutory dissolution being the prime examples-are collective decisions; direct restrictions on alienation tend to require the affected individual owner's consent. ${ }^{23}$ Now, lowever, CTS has blessed the extension of collective decisionmaking even to this aspect of stock ownership and, in order to keep it under state rather than under federal supervision, placed it under the internal affairs umbrella.

It is laudable that the Court uses the internal affairs legitinate doctrine as a means to avoid raising efficient-capital and control-market hypotheses to the level of constitutional doctrine via tlie dormant commerce clause, as Edgar v. $M I T E^{24}$ came dangerously close to doing. At the same time, lowever, the CTS Court comes dangerously close to

22. See, e.g., Seligman, Equal Protection in Shareholder Voting Rights: The One Share, One Vote Controversy, 54 GEO. WASH. L. REV. 687 (1986).

23. See REVISED MODEL BusinEsS CORP. ACT $\S 6.27$ (1984) and the commentary in MODEL Business CORP. ACT ANNOTATEd 428 (1985).

24. 457 U.S. 624 (1982). 
elnbedding another doctrine-the "state of incorporation" version of the internal affairs doctrine-in the Constitution via the saine clause. It is the aim of this paper to demonstrate that this approach, the constitutional "Delawarization" of state corporation law, is not what CTS intends or effects.

Traditionally, vertical conflict between federal and state regimes have been perceived differently from horizontal conflict between state regimes. The former typically has been examined under supreinacy and dornant commerce clause principles; the latter under principles derived from the full faith and credit clause. It is not news, however, that froin the perspective of free interstate commerce, collisions between the laws of different states can be as troubling as conflicts between state and federal laws. Indeed, this perception has led soine commentators to call for the treatment of these horizontal problems specifically under the commerce clause, ${ }^{25}$ and some of the passages of the Court's opinion in CTS seem to suggest that the Court is ready to heed that call. ${ }^{26}$

I propose to examine this constitutional matrix from the reverse direction, however - that is, from the perspective of the full faith and credit jurisprudence. If this jurisprudence has resolved commerce-type problems in the past, it may properly be used as a guide to resolve future conflicts between state statutes and to imterpret the "state-of-mcorporation primacy" passages of CTS. There is, in fact, considerable historical interest in reexamination of full faith and credit jurisprudence, since the older cases involved matters surprisingly similar to those now under discussion. It also is striking, however, how similar the pohicies that evolved

25. A major presentation of this position is Horowitz, The Commerce Clause as a Limitation on State Choice-of-Law Doctrine, 84 HARv. L. REv. 806 (1971).

26. Important to this point are the following passages, 55 U.S.L.W. at 4483:

This Court's recent Commerce Clause cases also have invalidated statutes that adversely may affect interstate commerce by subjecting activities to inconsistent regulations. . . . The Indiana Act poses no such problem. So long as each State regulates voting rights only in the corporations it has created, each corporation will be subject to the law of only one State. No principle of corporation law and practice is more firmly established than a State's authority to regulate domestic corporations, including the authority to define the voting rights of shareholders. See Restatement (Second) of Conflict of Laws $\S 304$ (1971) (concluding that the law of the incorporating State generally should "determine the right of a shareholder to participate in the administration of the affairs of the corporation").

... Every State in this country has enacted laws regulating corporate governance. By prohibiting certain transactions, and regulating others, such laws necessarily affect certain aspects of interstate commerce. This necessarily is true with respect to corporations with shareholders in States other than the State of incorporation. Large corporations that are listed on national exchanges, or even regional exchanges, will have shareholders in many States and shares that are traded frequently. The markets that facilitate this national and international participation in ownership of corporations are essential for providing capital not only for new enterprises but also for established companies that need to expand their businesses. This beneficial free market system depends at its core upon the fact that a corporation-except in the rarest situations-is organized under, and governed by, the law of a single jurisdiction, traditionally the corporate law of the State of its incorporation. 
from that jurisprudence are to the policies animating the (dormant) commerce clause and supremacy clause analyses of today. This approach, in addition, liappens to be particularly timely since efforts to subsume full faith and credit considerations (i.e., "horizontal") under commerce clause analysis (i.e., "vertical") liave begun to appear in the corporate law context, ${ }^{27}$ and undoubtedly will gain new momentum from the CTS opimion.

The Conflicts SPECTRUM of SubStantive CORPORATION LAW

At one time, European legal doctrime, addressing state-federal overlap in the area of antitrust law, distmguislied between rules that create two hurdles, witl the lower hurdle not mconsistent witl the demands of the higlier one, ${ }^{28}$ and rules that create genume conflicts of obeisance, ${ }^{29}$ witl one rule mandating what the otlier forbids. While it is an incomplete and inadequate analogy, one can say, roughly, that the function of the full faith and credit clause is to prevent excessively costly collisions of the latter kind between sister states. On the other liand, it would be the function of the supremacy clause or, failing a federal statutory hook, of the dormant commerce clause to nullify the liiglier state liurdle when the lower liurdle is a creation of a federal regime and reflects a belief that the person subject to that lower, federal lrurdle sliould not be subject to a higlier, state one. The full and faith and credit clause, however, cannot as readily or legitimately negate the liiglier state liurdle in the case of differmg (as against absolutely conflicting) legislative or judicial policy judgments-liurdles - of coequal sovereign states. ${ }^{30}$ In other words,

27. This subsumption is argued explicitly in Kozyris, Corporate Wars and Choice of Law, 1985 DUKE L.J. 1, 57-61 and implicitly in DeMott, Perspectives on Choice of Law for Corporate Internal Affairs, 48 LAW \& ConTEMP. PROBS. 161 (Summer 1985). See also Horowitz, supra note 25.

28. See the description in Koch, Das Verhältnis der Kartellvorschriften des EWG-Vertrages zum Gesetz gegen Wettbewerbsbeschränkungen, 14 BETRIEBS-BERATER 241 (1959), in which the concept, in its modern use, originated. For a discussion of its subsequent transformation, see W. MÖSCHEL, RECHT DER WETTBEWERBSBESCHRÄNKUNGEN 133, at 89-90 (Cologne 1983).

29. Cf. Buxbaum, Securities Regulation and the Foreign Issuer Exemption: A Study in the Process of Accommodating Foreign Interests, 54 CORNELl L. REV. 358, 372 (1969); 3 A. Ehrenzweig \& E. Jayme, Private International Law $27-29$ (Leyden 1977) (placing the concept in its general private international law context).

30. During the New Deal period a somewhat more aggressive role was envisaged for the full faith and credit clause, as is clear from the classic address by Justice Jackson, Full Faith and Credit-The Lawyer's Clause of the Constitution, 45 CoLUM. L. REV. 1, 17 (1945) (citation omitted): "[The full faith and credit clause] was placed foremost among those measures which would guard the new political and economic union against the disintegrating influence of provincialism in jurisprudence ...." The amendment of the Judiciary Act of 1790 in 1948 to include "Acts of the legislature" (i.e., statutes) in the catalog of respected state actions, Act of June 25, 1948, ch. 646, 62 Stat. 947 (codified as amended at 28 U.S.C. $\S 1738$ (1982)) was taken by some at that time to confirm this strong role. See Cheatham, $A$ Federal Nation and the Confict of Laws, in LectURES ON THE 
while the full faith and credit clause may well be a more specific and more sharply focused constraint on exorbitant forum choice of law adventures than the supremacy and the commerce clauses, the latter could come into play under at least some "vertical" circumstances to invalidate state corporation law rules even if these would not violate the full faith and credit clause.

Before exploring these doctrinal relationships in more detail, it is necessary to review the typical corporation code choice of law rules to categorize them accordimg to the degree to which they can generate even the two-hurdle let alone the conflict-of-obeisance problem.

\section{A. The Peripheral Problems}

Most of the substantive internal affairs rules apphied via the secondgeneration choice of law provisions do not rise even to the level of the two-hurdle problem. Code provisions granting shareholders rights of information and inspection and providing remedies to implement those rights may create trivial management costs to the corporation, but such costs are too msignificant to create problems of corporate law policy. No corporations code trumpets a managerial right to silence or a prohibition on shareholders' inspection rights. Rather, to the degree that differences between states are intended and not simply madvertent, such differences are at the most due to relatively minor differences in cost-benefit judgments. Whether all or only corporations of a certain size should provide audited rather than unaudited statements might be the extent of the substantive difference that this type of provision can reflect. ${ }^{31}$ Such a trivial difference hardly can be dignified with a burden analysis of the type Pike v. Bruce Church, Inc. ${ }^{32}$ calls for under the commerce clause, ${ }^{33}$ let alone with the kind of dilemma analysis necessary under the full faith and

CONFlict of LAwS AND INTERNATIONAL ConTracts 193, 197 (reprint ed. 1982). Much of this view still informs the analysis of Kozyris, supra note 27.

See also Hay, Full Faith and Credit and Federalism in Choice of Law, 34 MERCER L. REv. 709, 723 (1983) (quoting Currie, The Constitution and the Choice of Law: Governmental Interests and the Judicial Function, 26 U. Chil. L. REv. 9 (1958)):

As such, federalism should require more than a one-way deference to states' rights in matters of choice of law. It also must encompass the obligation of 'each state . . . to give due deference to the laws of other states' as well as to the needs of the interstate system as a whole.

31. See, e.g., the detailed prescription in CAL. CORP. CODE $\S 1501$ (a), (d) (West Supp. 1987).

For a review of shareholder information statutes, see DeMott, supra note 27, at 167-170.

32. 397 U.S. 137 (1970).

33. This assumes that, however attenuated, a link between something like a shareholder's inspection right and an effect on interstate commerce can be conceived. For a current sense of the outer reach of the commerce clause argument in the case of technical corporation law provisions, see G.D. Searle \& Co. v. Cohn, 455 U.S. 404, $412-14$ (1982) (remand for consideration of whether commerce clause is violated by state practice of discriminating against out-of-state corporations in application of statute of limitations if corporation declines to appoint in-state agent for service of process); Valtz v. Penta Inv. Corp., 139 Cal. App. 3d 803, 808-09, 188 Cal. Rptr. 922, 925-26 (1983) 
credit clause. This conclusion is all the more warranted if the reach of the local rule-a broader information requirement, for example-is limited to corporations in which a substantial number or even majority of shareholders are residents of the forum asserting prescriptive jurisdiction. This is the case, for example, with section 2115 of the California Corporations Code. ${ }^{34}$

Another type of local provision fits within this "minimal burden" group - the availability of a particular legal process, the derivative suit, to the shareholders of even a foreign corporation. Part of the reason for this conclusion is that every American jurisdiction provides this action. ${ }^{35}$ The differences, if they exist, are at highly refined levels of detail: who may bring the action; the formal prerequisites to its maintenance; when, if ever, the plaintiff is required to give security for costs; the fornnal conditions under which the directors may compromise and settle or approve dismissal of an already mstituted action; etc. Whether these elements are procedural or substantive, ${ }^{36}$ they do not reflect such significant philosophical differences among the states as to engender a burden let alone a dilemma analysis. The reverse hypothesis is instructive: The derivative suit concept, though an "internal affairs" matter, is not so substantive that in a case involving a foreign corporation a forum court would have to make it available by reason of the full faith and credit clause were it otherwise unknown to the law of the forum. ${ }^{37}$

(rejecting argument that interstate commerce is affected by statute imposing shareholder list inspection duties on corporation having its principal executive office located in state).

34. See Buxbaum, The Application of California Corporation Law to Pseudo-Forelgn Corporations, 4 CAL. Bus. L. RPTR. 109, 112 (1983); but see DeMott, supra note 27, at 171.

Even a burden of this sort could conceivably be based upon a purpose that goes beyond the bounds even of the enlightened free enterprise philosophy that is adorned rather than embarrassed by a "full disclosure" requirement, thus implicating the commerce clause. The inspection right, for example, might be granted to creditors or employees. While not everyone would call this socialism, such a grant could generate at least the kind of efficiency debate that state takeover legislation has generated. To this issue, too, then, the implications of Edgar v. MITE Corp. might be remotely relevant. Nonetheless, it should be obvious that commerce clause considerations do not cloud the right of states to impose the kind of local information rules that exist today, especially given their minimal variation among jurisdictions.

35. And equally to the point, these jurisdictions typically explicitly authorize derivative suits on behalf of foreign corporations, probably on a justified principle of uniformity. See 2 MODEL BUSINESS CORP. ACT ANNOTATED § 49, 3.02 (1985).

36. On the outcome-determinative test in the federal Erie vocabulary, see Hanna v. Plumer, 380 U.S. 460 (1965).

37. A forum court may refuse to entertain a derivative action on behalf of an alien corporation not otherwise significantly connected with the forum state, when the law of the place of incorporation does not recognize the action in the first place. Hausman v. Buckley, 299 F.2d 696 (2d Cir.), cert. denied, 369 U.S. 885 (1962); see also Kaplan, Foreign Corporations and Local Corporate Policy, 21 VAND. L. REv. 433, 461-64 (1968). That doctrine, however, would not override a statutory command to make the procedure available in such a situation. See Norlin Corp. v. 


\section{B. Minor Substantive Problems}

At the present stage of choice of law claims in corporation law, then, the relatively rare complaint against application of local derivative suit procedures does not approach the realm of constitutional concern, given the availability of fairly similar procedures in all jurisdictions. ${ }^{38}$ of potentially greater concern is the much more prevalent choice of forum law rule hidden in the now common curative statutes bearing on the prudence and loyalty of directors and officers. These choice of forum law rules carry the potential for altering the substantive definitions of "fairness," through a more (or less) stringent substantive law of fiduciary inanagerial duty apphed to the decisions of foreign corporations. If the forum law imposes a higher standard of loyalty (or care) on the management of a foreign corporation than would be the case under the law of the place of incorporation, a genuine two-hurdle situation is created. It is, however, only a two-hurdle case, not a dilemma case; the state of incorporation's less deinanding law certainly poses no problems to a management honoring the foreign forum's higher standards. What is involved, rather, is a question of burden. The burden issues caused by the differing actions of coequal state sovereigns are nornally not disruptive enough to trigger federally imposed harmony via the full faith and credit clause. That these burdens might, as a pohitical matter, cause Congress to preempt such inconsistent state legislation under a statute triggering federal supremacy clause review is another matter. Whether this is a correct or defensible reading of the current law will be considered below; for the moment it is enough to identify the viewpoint.

The two-hurdle or burden issues, however, can generate commerce

Rooney, Pace Inc., 744 F.2d 255, 261 (2d Cir. 1984) (applying N.Y. Bus. CoRP. LAw § 1319(a)(2) (McKinney 1986)).

To the extent that Hausman rests on a forum non conveniens argument, that prudential ground for dismissal would remain available to the New York court unless itself explicitly countermanded by statute. Cf. Panama Processes, S.A. v. Cities Serv. Co., 650 F.2d 408 (2d Cir. 1981) (direct suit between alien and American corporate parents of Brazilian subsidiary dismissed, over persuasive dissent, on forum non conveniens grounds). But $c f$. Rocha Toussier y Asociados, S.C. v. Rivero, 91 A.D.2d 137, 457 N.Y.S.2d 798 (1983) (accepting local derivative suit instituted by foreigu association's receiver despite pending appeal in Mexican courts to determine receiver's status).

It can be argued, perhaps ironically, that the resurgent use of the forum non conveniens notion to avoid difficult choice of law issues, per Piper Aircraft Co. v. Reyno, 454 U.S. 235 (1981), amounts to a full circle return to the origins of the internal affairs doctrine as a forum derogation method. $C f$. Kay, Theory Into Practice: Choice of Law in the Courts, 34 MERCER L. Rev. 521, 584 (1983).

38. The rather subtle ways in which these derivative suit issues are transformable into substantive confiict of laws issues (primarily because of the interaction of substantive fiduciary principles with the procedural threshold problems of maintaining these suits) are beyond the scope of this discussion. See generally Buxbaum, Conflict-of-Interests Statutes and the Need for a Demand on Directors in Derivative Actions, 68 CALIF. L. REv. 1122 (1980). 
clause arguments in extreine cases, ${ }^{39}$ and thus should be scrutinized within some framework of values attentive to those arguments. The possibility that laissez faire values animate the commerce clause and its preemption of regulatory state law obviously will be relevant to this analysis as well. Even so, it seems clear that states sharing a common, underlying adherence to a free market economy can still propound fiduciary standards that vary in their stringency. The inost that could be said against such varying standards is not that any given one is incompatible with the efficient allocation of resources-for that concept depends upon and does not dommate a given set of legal rules-but that the uncertainties created by differing fiduciary standards to management muddy investment decisions somewhat and inake investment signals harder to identify clearly. Whether that categorical objection can rise to a level of pathos triggering constitutional relief is best left to a discussion of those more serious conflicts among substantive rules found in the fourth group, the group of true conflicts of obeisance.

\section{The Paradigmatic Conflict: Cumuiative and Ordinary Voting}

The most important, and perhaps only, example of a true conflict of obeisance stems from California's application of its mandatory rule of cumulative votimg for the election of directors to those corporations within the definition of "pseudo-foreign" entities under Section 2115 of the California Corporations Code. ${ }^{40}$ This is the substantive rule at issue in the only American decisions that have considered the implications of the full faith and credit clause im a modern company law context, the well-known and often-analyzed case of Western Air Lines, Inc. $v$. Sobieski, ${ }^{41}$ and the recent case of Wilson v. Louisiana-Pacific Resources, Inc. ${ }^{42}$

For a company potentially subject to two different rules of voting, a conflict of obeisance arises in two senses. First, there is the formal problem that the same election, the same event, may be subject to conflicting mandates; it is not possible to vote straight and cumulatively at the same time because the two methods will produce different results. ${ }^{43}$ Either directors $A$ through $G$ are elected or $A$ through $D$ plus $H, I$ and $J$ or soine

39. For a good discussion of this point, see Wilson v. Louisiana-Pacific Resources, Inc., 138 Cal. App. 3d 216, 225-28, 187 Cal. Rptr. 852, 858-61 (1982).

40. CAL. CoRp. CoDE $\S 2115$ (West Supp. 1987).

41. $191 \mathrm{Cal}$. App. 2d 399, 12 Cal. Rptr. 719 (1961). Its sequels are Western Air Lines, Inc. v. Schutzbank, 258 Cal. App. 2d 218, 66 Cal. Rptr. 293 (1968) and People v. Western Air Lines, 258 Cal. App. 2d 213, 66 Cal. Rptr. 316 (1968). For a discussion of the primary case, see Kaplan, supra note 37 , at $453-55$.

42. 138 Cal. App. 3d 216, 187 Cal. Rptr. 852 (1982).

43. See the sequence of litigation described in Palmer v. Arden-Mayfair, Inc., 47 U.S.L.W. 2055 (Del. Ch. June 6, 1978). 
variant thereof. By contrast, a management transaction valid under the more stringent of two fiduciary rules also is valid under the less stringent. In short, the cumulative votmg dilemma cannot be treated as a two-hurdle problem.

In addition, both the efficiency and the fairness considerations which may be trivial in the prior examples cannot be shrugged off so lightly in this case. A major shareholder may legitimately expect that full domination of the board of, say, a Delaware corporation can be achieved with at least fifty-one percent, if not less, of the share ownership. This expectation will be disappointed in a significant sense once a state like Califorina applies its rule of inandatory cumulative voting to the corporation. The state of incorporation's umit voting rule may or may not represent a conscious pohicy choice of majoritarianism. Regardless of the policy, the fact that an investor may place more weight and expectations on the unit-voting rule makes the direct conflict more serious here than in the two-hurdle situations previously discussed.

Disappointed investor expectations, however, do not rise to the level of substantive constitutional clains uuless they involve the taking of property without due process of law or the denying of the equal protection of the laws. In the area of shareholder property rights within the corporate structure, such clanns have been unsuccessful since the courts abandoned substantive due process scrutiny and rigorous equal protection scrutiny of "economic" statutes. For historical reasons, intrusion on shareholder expectations through the statutory cliange of governance groundrules was analyzed as an impairment-of-contracts problem. This problem was eliminated witl the adoption of the so-called "reserve power" in state constitutions after Trustees of Dartmouth College v. Woodward. ${ }^{44}$ As a result of this evolution, the direct concern with owners' property rights has not served as the basis for the application of the full faith and credit clause to these situations. Instead, nistitutional concerns of the kind that underlie the commerce clause on the whole have always been a feature of full faith and credit clause jurisprudence. It is not the particular investor but the protected institution-whether private investment or the private enterprise econoiny, or the compatible functioning of courts, legislatures, and agencies in a dual sovereign systemwhose claims trigger analysis. Thus, even if under one view commerce clause principles do lurk behind full faith and credit clause doctrine, it may be equally valid to say that the latter doctrine should inforn and

44. 17 U.S. (4 Wheat.) 518 (1819). For a full discussion of the impact of this reservation of power on the expectations of shareholders, see the two classic judicial expositions, McNulty v. W. \& J. Sloane, 184 Misc. 835, 838-46, 54 N.Y.S.2d 253, 257-63 (Sup. Ct. 1945) and Bove v. Community Hotel Corp. 105 R.I. 36, 45-51, 249 A.2d 89, $95-98$ (1969). See also Carney, Fundamental Corporate Changes, Minority Shareholders, and Business Purposes, 1980 AM. B. Found. RES. J. 69, 77-97. 
influence the still-evolving role of commerce clause review of the modern corporation law provisions now under discussion.

That proposition is best tested by the hardest case, that of a true, if rare, collision between incoinpatible statutory mandates. Western Air Lines, Inc. v. Sobieski $i^{45}$ is the prototype of this fourth group of transactions. Western, originally incorporated in California, had reincorporated in Delaware under circumstances permitting an argument that it had accepted the continumg jurisdiction of the California Blue Sky agency. Almost thirty years later, it proposed a shareholder resolution to eliminate cumulative voting, mandatory in California but permissive rather than mandatory in Delaware. The California Commissioner of Corporations properly asserted that this change in the rights, preferences, and privileges of the shares constituted a sale under the broad definition contained in the California Corporations Code. ${ }^{46}$ That deternination was not subject to dispute, since it was simply a matter of statutory interpretation. The Commissioner then demied Western's application for a permit on the ground that the change to unit voting was not "fair, just and equitable" in terms of the statutory language governing the grant of a permit to "issue" shares. By doing so, the Commissioner applied California's mandatory cumulative voting law to the internal affairs of this Delaware corporation, on policy grounds that liad to do with the substantial (tliougli by no ineans predommant) colmection of the company to California. ${ }^{47}$ The Commissioner's action was uplield by an internediate appellate court, again on the basis of the (1misleadingly designated) pseudo-foreign cliaracter of the company. ${ }^{48}$ No full faith and credit argnment concerning the refusal of the court to apply the law of the state of incorporation to this transaction was debated in the course of the litigation.

This, then, is a situation in which the company was refused permission to conduct the shareliolders' election of the board of directors in a manner that the law of the state of incorporation would have pernitted. It is not, however, a case in wlicli umit-voting was mandated by the law of the state of incorporation. That mandate would eitlier spring from a specific statutory prohibition of cumulative voting, ${ }^{49}$ or from a judicial decision holding that a law permitting either method and a charter

45. 191 Cal. App. 2d 399, 12 Cal. Rptr. 719 (1961).

46. The current definition can be found in CAL. CoRP. CODE $\S 25017$ (a) (West Sup. 1986).

47. Western Air Lines, 191 Cal. App. 2d at 402-03, 12 Cal. Rptr. at 721-22.

48. Id. at $412-13,12 \mathrm{Cal}$. Rptr, at 727-28.

49. See the (perhaps only) statute so interpreted in State ex rel. Kearns v. Rindsfoos, 161 Ohio St. 60, 65, 118 N.E.2d 138, 141 (1954). In Palmer v. Arden-Mayfair, Inc., 47 U.S.L.W. 2055 (Del. Ch. June 6, 1978) the Delaware statute's authorization of either type of voting, combined with the company's charter choice of straight voting, led the court, in dicta, to prohibit application of California's statutory mandate of cumulative voting, a doubtful statement. 
choice of unit voting would together require unit voting. While both situations have arisen, ouly the latter has provided enough experience ${ }^{50}$ to afford an opportunity for analysis of current full faith and credit doctrine. ${ }^{51}$

\section{The Constitutional Issue}

The corporation law full faith and credit cases are few and, according to current consensus, no longer fully respectable. ${ }^{52}$ The broader full faith and credit doctrine, fruitfully enriched if not simplified by Allstate Ins. Co. $v$ Hague, ${ }^{53}$ has moved away from many of the assumptions underlying these few and older corporation cases.

The internal affairs doctrine- that the internal affairs of a corporation norinally should be governed by the law of the state of incorpora-

50. A statutorily based impairment-of-contracts doctrine was used to hold that a bylaw provision for unit voting was not disturbed by a subsequently passed mandatory cumnlative voting statute in State ex rel. Swanson v. Perham, 30 Wash. 2d 368, 376, 191 P.2d 689, 694 (1948). It was overruled, however, on modern "reserved power" concepts, see supra note 44, in Seattle Trust \& Sav. Bank v. McCarthy, 94 Wash. 2d 605, 610, 617 P.2d 1023, 1027 (1980). That court made the additional observation (relevant to the discussion of the full faith and credit issue in the text immediately following) that a shareholder not directly owning a majority of the voting stock had no legally protectible expectation of being in the majority, whose influence could be diluted by cumulative voting, since one's membership in the majority "vests" only at the time a given vote is taken. Id. at 607 n.2, 617 P.2d at 1026 n.2. It thus was possible that the heavy artillery of the reserved power argument was not even necessary.

51. It also provides an opportunity for critical examination of $\S 302$ of the RESTATEMENT (SECOND) OF THE CONFLICT OF LAwS. Subsection two of $\$ 302$ allows the law of the state with the "more siguificant relationship" to intrude on the monopoly of the law of the state of incorporation. Comment a extends this possibility to a range of internal affairs, including cumulative voting, but comments $e$ and $g$ then take most of this freedom away, with the assertion that, "[i]n addition, many matters involving a corporation cannot practicably be determined differently in different states. Examples of such matters, most of which have already been mentioned in Comment a, include . . . methods of voting including any requirement for cumulative voting . ..." RESTATEMENT (SECOND) OF THE CONFLICT OF LAWS at comment e (1969).

See also, in this mode, Young, Federal Corporate Law, Federalism, and the Federal Courts, 41 LAw \& ConTEMp. Probs. 146, 148 (Summer 1977) and Kirgis, The Role of Due Process and Full Faith and Credit in the Choice of Law, 62 CORNELl L. REV. 94, 139-42 (1977).

For criticisms of the SECOND RESTATEMENT's approach from the private law perspective of interstate and international conflict of laws, sec Kaplan, supra note 37, at 440-41. A fortiori, the apotheosis of such a rule through constitutional dictates should be viewed even more sceptically-as indeed it is in Shaffer v. Heitner, 433 U.S. 186, $215 \mathrm{n} .44$ (1977). For recoguition of this restraint, see DeMott, supra note 27, at 161-62. But cf. Kozyris, supra note 27, at 40-45 (supporting state-ofincorporation primacy on constitutional grounds). See generally Pinto, Takeover Statutes: The Dormant Commerce Clause and State Corporate Law, 41 U. Mrami L. REv. 473 (1987).

52. For a full and still valid historical and analytical discussion, see Weintraub, Due Process and Full Faith and Credit Limitations on a State's Choice of Law, 44 IOWA L. REV. 449, 529-30 (1959), reprinted in revised form in R. WEINTRAuB, COMMENTARY ON THE CONFLICT OF LAwS $495-547$ (2d ed. 1980); see also Kaplan, supra note 37, at 446-47.

53. 449 U.S. 302 (1981). For discussion of this case, see Symposium: Choice-of-Law Theory After Allstate Insurance Co. v. Hague, 10 HofsTrA L. REv. 1 (1981); Brilmayer, Legitimate Interests in Multistate Problems: As Between State and Federal Law, 79 MICH. L. REv. 1315 (1981). 
tion-began as a forum derogation concept. ${ }^{54}$ Early courts, called on to provide relief to some sliareliolders (or creditors) of a foreign corporation, understandably were unsure whether their jurisdictional reacli was broad enough to gnarantee that they could grant complete ratlier than partial or, worse, inconsistent relief. Exactly this kind of concern underlies the early full faith and credit cases-they are only four in numberfrom which a constitutional bar to the imposition of foruin state law on foreign corporations might conceivably be inferred. ${ }^{55}$ They concerned mutual insurance coinpanies, rather than ordinary corporations, and they involved the problem of inconsistent state court reaction to bylaw changes or directors' resolutions bearing on the financial riglits and obligations of the insured coinpany members. A single quotation from the first of these cases should suffice to demonstrate both the source and the limits of that concern which led the Court to enshrine the "internal affairs" choice of law rule in the full faith and credit clause:

The contradiction in terms is apparent which would rise from holding on the one hand that there was a collective and unified standard of duty and obligation on the part of the members themselves and the corporation, and saying on the other hand that the duty of members was to be tested isolatedly and individually by resorting not to one source of authority applicable to all but by applying inany divergent, variable and conflicting criteria. $^{56}$

Professor Weintraub, who has provided the authoritative doctrinal explanation of this line of cases, characterized this particular line as properly concerned with the need for a uniform application of law in certain situations:

In many crucial areas there is need for national uniformity of conduct. ... In order to determine whether the full faith and credit clause places a further limitation on a state's choice of law than is imposed by the due process clause, the interest of the state that makes application of its law consistent with due process is to be weighed against the need for national uniformity of result under a public act, record, or judicial proceeding of a sister state. ${ }^{57}$

This concept of uniformity replaced an older "weighing" or "balancing" test, and now has becoine accepted Supreme Court dogma. ${ }^{58}$ In

54. See Buxbaum, The Origins of the American "Internal Affairs" Rule in the Corporate Conflict of Laws, FS Kegel 445, 464 (Munich 1987).

55. Order of United Commercial Travelers of Am. v. Wolfe, 331 U.S. 586 (1947); Sovereign Camp of the Woodmen of the World v. Bolin, 305 U.S. 66 (1938); Modern Woodmen of America v. Mixer, 267 U.S. 544 (1925); Supreme Council of the Royal Arcanum v. Green, 237 U.S. 531 (1915). These are presented and discussed in R. WEINTRAUB, supra note 52, at 524-30.

56. Supreme Council, 237 U.S. at 542.

57. R. WeintraUB, supra note 52, at 528.

58. Allstate Ins. Co. v. Hague, 449 U.S. 302 (1981). Indeed, Professor Weinberg suggests that not even this issue of "necessary uniformity" underlies current Supreme Court doctrine, but that 
and of itself, it provides no direct guide for our particular problems of conflicting state law. The very weakness of a mininun "uniformity" scrutiny, however, suggests that only procedural and remedial concepts-particularly questions of preclusion of parties and issues-are at the heart of any individualized, properly discriminating differentiation between truly intractable interstate conflicts and lesser, though still unsettling, problems of conflicting inandates. ${ }^{59}$

The cumulative voting dilemma demonstrates these points in detail. If a California court, first properly seized of the action, held that forum law rather than the law of the state of imcorporation governs the question of the manner of shareholder election of directors, and ordered a forthcoming election to be held under cumulative voting procedures, the only possible awkwardness that could arise would be a later conflicting decision of a Delaware (or federal) court ordering unit voting at the same election. It is just this kind of second, conflicting decision that the full faith and credit clause precludes, since the clause apphies preeminently to the judgments of a sister state, whatever the scope of its apphication to statutes and records. ${ }^{60}$ The critical question, in other words, is not whether two statutes or two cominon law rules may in the abstract require inherently incompatible action from a corporation, but whether mundane state law concepts such as res judicata or collateral estoppel are available to preclude a second and mconsistent coercive judicial mandate, or whether it is necessary to haul out the constitutional artillery and achieve that effect through the full faith and credit clause. In this field, at least, the clause is no more than a constitutional adjunct to ordinary problenıs of civil procedure; Allstate has amply reconfirmed this observation. ${ }^{61}$

The preceding discussion assumes a conflict between the state of mcorporation's common law choice of law rule (that the law of the state of incorporation goverus the internal affairs of the corporation) and the forum state's statutory choice of law rule (that the law of a state with

only the relaxed standard of "minimal scrutiny" of rational purpose now exists. Weinberg, Choice of Law and Minimal Scrutiny, 49 U. CH1. L. REv. 440, 444 (1982).

59. The requirement of significant contacts as justification for a forum's choice of local law in class actions, set out in Phillips Petroleum Co. v. Shutts, 105 S. Ct. 2965 (1985), does not change this analysis, since the type of contacts with the corporation's "home" state discussed in the accompanying text easily meet this threshold requirement.

60. Despite the dissenting argument of Walker, $A$ Criticism of Professor Weintraub's Presentation of Full Faith and Credit to Laws, 57 IowA L. REv. 1248 (1972), this is the prevailing understanding of the statutory change in the phrasing of the 1948 implementing legislation, see supra note 30, adding "Acts" to the previous list of items deserving full faith and credit.

61. Professor Kozyris's recent comprehensive analysis of the impact of Allstate, although critical of the development, agrees with this description. See Kozyris, supra note 27, at 32. For a similar perception that Allstate limits full faith and credit analysis to procedural due process, see Fassberg, The Forum: Its Role and Significance in Choice-of-Law, 84 ZVGLRWiss 1, 42-43 (1985). 
certain significant relationships with the corporation governs certain internal affairs of the corporation). The discussion further assumes that a court of the "statutory" state first adjudicates a given dispute, and that the courts of the "common law" state then are bound by the full faith and credit clause to award that decision party-preclusive effect. The analysis is no different if either or both variables are reversed: If the state of incorporation statutorily inandates apphication of the law of the state of incorporation to the internal affairs of such a corporation, or if a court of the state of incorporation is first seized of a given cause. For example, if Delaware were to codify its choice of law rule, it would add nothing to a Delaware court's right to have its first judgment honored in California, nor mitigate its legal inability to ignore an earlier California court's judginent. Conversely, a California court would be as bound by an earlier Delaware judgment (when the same parties relitigate an issue there that would be caught by res judicata or collateral estoppel principles were it relitigated before the earher-seized court) as in the prior, "reverse" example. ${ }^{62}$

It is obvious that a race to the courthouse is a potential, and potentially ugly, aspect of this element of the American federal system. Indeed, the coinpetitive litigation problem may affect more than just the instant election, since certam types of remedies may preclude the second state forum from ever getting the opportunity to address the question with respect to the particular corporation. For example, if the first action combines a request for a declaratory judgment with a request for a mandatory injunction that all elections for directors of the corporation thereafter be held under a cumulative voting (or umit voting) regime or for a negative injunction that the disfavored mode not be used, that first court's action inay be permanently preclusive on all other courts under full faith and credit primciples. In short, either a certain degree of chaos (if the race is run time and time again) or a certain degree of arbitrary victory (if the outcoine of the first race can somehow be cast in stone) is an inescapable component of the inutual sovereign system. This is not, in my opinion, a reason for recourse either to the full faith and credit clause or to the due process clause. These results can be accepted as a bearable

62. For a recent intimation that even such an agency might be blocked under full faith and credit, see Underwriters Nat'l Assurance Co. v. North Carolina Life \& Accident \& Health Ins. Guar. Ass'n, 455 U.S. 691 (1982). This would depend upon the offensive or defensive use of a nonmutual collateral estoppel claim. See RESTATEMENT (SECOND) OF JUDGMENTS $§ 29$ (1982).

There is one interesting though narrow escape from this preclusion argument just in the field of corporation law. It is possible that a state administrative agency, not involved in the first judicial hearing of a given transaction, may claim the right to reopen the transaction and, of course, to reach a different substantive result. An example would be a state securities regulation office reviewing the legitimacy of a transaction such as a merger or other structural decision effected under ordinary corporation law enabling provisions and already tested in a first judicial proceeding in a state other than that of the agency. 
cost of legitimate dual (perhaps even multiple) state sovereignty within a federal system, just as they are in areas outside of corporation law.

II

\section{From Procedure to Substance: From Full FaIth AND CRedit TO PREEMPTION AND COMMERCE Clause Questions}

\section{A. The Role of Due Process Considerations}

The limited role of the modern full faith and credit clause now can be illustrated by application of the Allstate case. ${ }^{63}$ Once the right of the state court to exercise jurisdiction over the appropriate defendants-itself a mixture of party and institutional concerns ${ }^{64}$ - has been established, as it admittedly was in Allstate, consideration of the choice of law is in order. It is common ground between the two inajor competing approaches to choice of law analysis that here, too, both personal and institutional concerns are involved; but there is some dispute whether both are best subsumed within a full faith and credit analysis or whether the personal issues should be analyzed under some, perhaps a unique, version of due process. ${ }^{65}$ For present purposes it is not necessary to trace this dispute, but the following quotation from Justice Stevens, a proponent of the latter approach, does help focus the discussion on the specific corporation law sector of this constitutional debate:

[T]wo separate questions must be answered. First, does the full faith and credit clause require Minnesota, the forum State, to apply Wisconsin law? Second, does the due process clause of the Fourteenth Amendment prevent Minnesota froin applying its own law? The first inquiry implicates the federal interest $\mathrm{m}$ ensuring that Minnesota respect the sovereignty of the State of Wisconsin; the second implicates the litigants' interest im a fair adjudication of their rights. ${ }^{66}$

Analyzing the full faith and credit issue, Justice Stevens stated what is today a consensus:

[I]n view of the fact that the forum State is also a sovereign in its own right, in appropriate cases it may attach paramount importance to its own legitimate interests. Accordingly, the fact that a choice-of-law decision may be unsound as a matter of conflicts law does not necessarily implicate the federal concerns embodied in the Full Faith and Credit

63. 449 U.S. 302 (1981).

64. For a discussion of due process limitations on state claims of in personam jurisdictiou, see World-Wide Volkswagen Corp. v. Woodson, 444 U.S. 286, 291-94 (1980). But see Insurance Corp. of Ireland, Ltd. v. Compagnie des Bauxites de Guinee, 456 U.S. 694, 702 n.10 (1982) (calling into question World-Wide Volkswagen's statement that federalism concerns play a role distinct from individual interests in the personal jurisdiction standard).

65. This is the point at issue between the plurality and concurring opinions in Allstate.

66. Allstate, 449 U.S. at 320 (Stevens, J., concurring) (footnotes omitted). 
Clause. Rather, ... the Clause should not invalidate a state court's choice of forum law unless that choice threatens the federal interest in national unity by unjustifiably infringing upon the legitimate interests of another State. ${ }^{67}$

At this point an accounting of the category and the intensity of the forum's interest typically follows, and typically leads, as it did in Allstate, to validation of the forum's choice of law. ${ }^{68}$ And, again typically, dormant commerce clause considerations do not play an unduly prominent role at this stage.

While Justice Stevens did not similarly explain the nature of the second issue of due process analysis, his approving citation of Weintraub's discussion thereof provides sufficient information. ${ }^{69}$ The key element is the "unfair surprise" to a party of having forum law applied to its dispute. Specifically, it is the "unfair surprise" to its justified expectation that a chosen or predictable law-important to any decision of the party concerning the best use of its resources-would apply to that decision. Professor Weintraub's exainples are those of insurance companies which issue policies and set premiums in situations in which the choice of law is material in actuarial terms. ${ }^{70}$

So understood, the influence of institutional and private concerns on each otlier and thus on the application of eitlier a unitary or a twopronged full faith and credit/due process test is clear. An interesting scissors effect emerges in the contractual context discussed by Weintraub. On the one hand, the more autonomy a party has to choose the law applicable to the contract, the inore it can conjure with the unfair surprise element. On the other hand, the inore it uses its autonomy to reinove itself from the natural control of the state in which its transactions naturally have their impact, the less surprise can it claim when the force of gravity emanating from that state pulls the transactions back within its control through choice of law revisions. In short, neither the objecting party's personal claims nor the federal system's institutional claims overcome the forum's claiuns to its own law unless there is no legitimate gravitational pull to the forum state; that is, unless the forum's connection with the transaction is so mimimal tliat choice of its own law would violate choice of law principles in the same sense that a forum's exorbitant jurisdictional claims iniglit violate parallel principles applicable to jurisdiction. Specifically, the federal constitutional context adds alinost nothing to the equation that otlierwise applies to the competition of coequal sovereigns as it might occur in, say, the international setting

67. Id. at 323 (footnote omitted).

68. See Weinberg, supra note 58 , at 442.

69. Allstate 449 U.S. at 327 n.16.

70. Weintraub, supra note 52 , at $457-60$. 
and its private international law regimes. ${ }^{71}$

If this conclusion is valid in the general area of contract law despite the countervailing value inherent in the direct interaction of the contracting parties' autonomous wills, how much inore should it be expected in corporation law where that expression of will is diluted to the point of invisibility by the mediating institutional realities of corporate investment and shareholding, and of the shareholder-director-officer hierarchies involved in corporate governance and decisionmaking?

An interesting forum non convemens internal affairs case, $O^{\prime} B$ rien $\nu$. Virginia-Carolina Chemical Corp.,$^{72}$ permits the integration of these various doctrinal and contextual strands and the application of the result to the foreign corporation choice of law problem. The plaintiff, a New Jersey resident and holder of one hundred preferred shares in the defendant, a moderately large Virginia corporation, had dissented from a typical recapitalization plan approved by a majority of that class. The plan called for elimination of a substantial arrearage of cumulative dividends by their partial capitahzation in an exchange of the prior stock for a new class. She brought suit in New Jersey; its courts had personal jurisdiction over the corporation because it had qualified to do (a minor amount of) business and had a registered agent located there, though it had no other connection with the state under any of the traditional tests of shareholder residence, plant and employee location, or sales. The merits of the dispute involved the interpretation and possibly the constitutionality (federal or state) of a change in the Virginia corporation law that allowed an amendment of the articles of incorporation necessary to the corporation's recapitalization plan. This was coinplicated by the effect of a summary, but potentially plenary, Virginia administrative review of the new share issuance under its Blue Sky regulation.

Reversing the lower court, the New Jersey Supreme Court properly decided that an action with so much internal Virginia law detail, which also entailed the risk that the forum state court might find it necessary to

71. See Note, Comparative Impairment Reform: Rethinking State Interests in the Conflict of Laws, 95 HARV. L. REV. 1079, 1091-92 (1982) (footnotes omitted):

Although policy-oriented theorists have seen policy analysis and territoriality as mutually exclusive approaches to conflict-of-laws adjudication, consideration of territorial contacts is in fact a means of assessing the existence and quantum of state interest.

....

... [S]ome kind of consideration of territorial contacts is essential in order to specify which states are interested in a given transaction. But to identify precisely which territorial contacts are relevant, a court must look to the class of transactions a state desired to affect, rather than searching vainly for some "touchstone" contact.

72. 44 N.J. 25, 206 A.2d 878 (1965), cert. denied, 389 U.S. 825 (1967); see also the "home" case concerning the same transaction, O'Brien v. Socony Mobil Oil Co., $207 \mathrm{Va} .707,152$ S.E.2d 278, cert. denied, 389 U.S. 825 (1967); and the discussion of the underiying facts and course of that litigation in Gibson \& Freeman, $A$ Decade of the Model Business Corporation Act in Virginia, 53 VA. L. REv. 1396, 1405-08 (1967). 
declare a sister state law unconstitutional, was best heard before a Virginia court. The court dismissed the action under appropriate protective conditions. ${ }^{73}$ It emphasized, too, those factors making New Jersey an mconvenient forum, which were, of course, the same elements that would have made a New Jersey choice of local law questionable to the point of constitutional infirmity under the above-described conditions: few New Jersey shareholders to protect, and no significant connection of the Virginia enterprise with New Jersey. These counecting strands did not localize the company sufficiently in New Jersey to justify application of local law to a locally "seated" person under a "nationality" rule restrained enough to be a serious rival to an "imcorporation" rule.

The justified expectations of the Virginia corporation do not exist in a vacuum but in a context that determines their legitimacy. Everything, in short, turns on the degree of the state's interest in the actions of the foreign corporation, and that in turn depends upon the degree of their mutual connection (as categorized, for instance, by the elements and weights of California's section $2115^{74}$ though not necessarily by those specific numbers). The important point remains the one articulated by the Supreme Court in a quite analogous insurance regulation case: "Nothing in the Constitution requires a state to nullify its own protective standards because an enterprise regulated has its headquarters elsewhere."75

\section{B. The Burden of Multiple State Claims}

It is clear then that the full faith and credit clause does not prohibit a state from applying its own law to a foreign corporation given a sufficient level of connection between the state and the corporation. The only significant borderline problem is whether a state other than the state of incorporation may define the degree of connection in such a way as to allow yet other states' laws to apply were they to use those same criteria. Does this possibility of multiple potentially apphicable corporation law rules distinguish the corporate setting from other settings?

The major aspect of the problem, that of a corporation facing potential conflicting inandates governing its behavior in a single transaction, already has been discussed in the choice of forum context and, one hopes, satisfactorily put to rest with the prior suggestion that appropriate rules of preclusion of parties from relitigating given transactions are ade-

73. This modern use of the original "internal affairs" doctrine, as a remedially and factually oriented forum non conveniens concept, of course does and should retain some vitality. See, e.g., Langfelder v. Universal Laboratories, Inc., 293 N.Y. 200, 204, 56 N.E.2d 550, 553 (1944); Prescott v. Plant Indus., Inc., 88 F.R.D. 257, 261-63 (S.D.N.Y. 1980); see also supra note 37.

74. CAL. CoRP. CODE $\S 2115$ (West $1977 \&$ Supp. 1987); see supra note 34.

75. Hoopeston Co. v. Cullen, 318 U.S. 313, 320 (1943). 
quately responsive to the constitutional concerns there. The preclusion concept, in its policy if not in all its technical contours, adequately responds to the choice of law problem, with one important qualification illustrated by the distinction between Western Airlines and O'Brien.

The important countervailing consideration to a forum's freedom to choose local law, at least in corporation law, may he in the preclusive force of precedent, not of res judicata. It is not critical that a given decision-preclusive as to a particular corporation and transaction-may be disregarded as precedent by later courts. If forum law concerning the fiduciary duty of directors is applied to find a foreign corporation's directors in breach as to a given transaction, disregard of that precedent in subsequent litigation im the state of imcorporation, on a fiduciary claim arising out of a different transaction involving the same corporation, agam is not significant. The rehance of these later hypothetical defendants on the lesson of the earlier holding is not qualitatively different from or more deserving of deference than rehance on any precedent of another or even of the same jurisdiction. That choice of law considerations lead to "overruling" of precedent in this context raises no greater constitutional issue, in and of itself, than does overruling precedent generally.

At the other preclusive end of the scale would be a cumulative voting case in which (unlike the actual Louisiana-Pacific case) a declaratory judgment and injunction obtained in the first tribunal established the "rule" of voting for that corporation not only for the first disputed election but also for the future. If the procedural context of the case were such as to bind all current shareholders-perhaps even all future shareholders-then that ruling indeed might require full faith and credit as to future elections in that corporation.

The only conceptually difficult cases are the few middle range ones such as $O^{\prime} B r i e n$, in which the transaction and holding at issue can only be characterized as comprising both transaction-specific and transactiontranscending elements. A construction of the corporation's charter under Virgima law in a Virginia court to permit retroactive elimination of a dividend arrearage by a Virginia corporation is technically only "precedent" if the same corporation is agam sued in New Jersey to prevent a later arrearage from being disposed of $i m$ the same way. It inight be possible, however, for the first court, under class action procedures, to structure the rehef so as to give it "status" consequences in rule-stating or contract-interpreting terms. If so, its holdnig may be preclusive as to the corporation in that later New Jersey suit. Even so, the first ruling would only be "precedent" in the event other, though similarly situated, Virginia corporations come to court in New Jersey.

In short, in choice of law as in choice of forum, if ordinary preclusion rules of civil procedure are fully operative, the problem is only one 
of good judgment, not one of constitutional dimensions. Extremes of misjudgment, of exorbitant local law claims, can be corrected under the full faith and credit clause just as extremes of exorbitant personal jurisdiction claims can be corrected under the due process clause. But categorical constitutional rules are no more needed in the field of corporation law than in such fields as contracts, torts, or family law, or in their public law analogues of consumer protection, health and safety regulation, or custody rules.

There is a lesson in the full faith and credit exercise for those who would conjure with exorbitant dormant commerce clause arguments in this corporation law setting. The extent of the lesson must be demonstrated by explicating the nature of the overlap between the two doctrines in this setting.

There is no simple dichotomy of jurisdiction between the two doctrines; the issue is not federal-state versus state-state conflicts. Those who would let commerce considerations influence full faith and credit analysis as well as those who find in full faith and credit considerations rational precedent to influence commerce analysis are agreed on that point. That leaves the formal issue whether the new type of state legislation in the new interstate takeover arena differs in some material way from the traditional type of state legislation or judicial doctrine challenged in full faith and credit hitigation. By "type" I do not mean the difference in the respective statutes' territorial claims. A state claim to reach foreign corporations is a definitional requisite of the state-state conflict. By the same token, even a state disclaimer to reach beyond locally incorporated corporations would not, as $C T S$ demonstrates, categorically prevent a hypothetical federal-state conflict from arising.

The legislative or common law "type" question, rather, rests on the nature of the business transactions at issue in the two settings; it is based specifically on the distinction between state control of the purchase and sale of shares, thought uniquely to inpact commerce clause concerns, and state control of other aspects of the internal affairs of corporations. That distinction was casually asserted in $M I T E,{ }^{76}$ summarily repeated in the appellate court opinion in CTS, ${ }^{77}$ analytically elaborated in the SEC's amicus curiae brief before the Supreme Court in the latter case, ${ }^{78}$ and definitively laid to rest in the Supreme Court's opinion there.

In one sense, the merging of share transfer control legislation within general state corporation law by $C T S$ can only be applauded. Acceptance of the SEC's distinctions as a basis for finding commerce clause

76. Edgar v. Mite Corp., 457 U.S. 624, 645 (1982).

77. Dynamics Corp. of Am., 794 F.2d at 263-64.

78. SEC, U.S. Urge Supreme Court to Find Control Share Statute Unconstitutional, 19 Sec. Reg. \& L. Rep. (BNA), 231 (Feb. 13, 1987). 
violations would have led either to absurdly formal rules undermclusive of the mischief they would seek to control, or to equally absurd substantive rules unbridled in their agressive potential towards the very area of "real" corporation law they purport still to respect as beyond their reach.

This mistaken and apparently rejected approach arises because of an overenthusiastic fascination with the "market" characterization of ownership. Investment, whether debt or equity, does not exist in itself, but in firms that provide goods and services; it is derivative, not autonomous. Commerce in investınent is a form of commerce in services; but it too is ouly a derivative form, a species of investment in invisibles as compared with other investment in services and in goods.

The cominerce clause heretofore has functioned in a fairly unitary way across the entire economic arena, no inatter that especially in its dormant version it is inherently a vehicle for political-legislative determinations. The risk that it will generate an aberrational jurisprudence in one subfield that in fact should not be characterized as deserving inore sacrosanct treatment unfortunately was not reduced by the SEC's effort to tame MITE while retaining its creation of this autonomous subset. To the extent $C T S$ substitutes a mixture of populist and managerialist attitudes for the "stock inarket subset" of coinmerce clause jurisprudence, it simply returus that subset to its place in the general doctrime. The concurrent apotheosis of the state of incorporation's prinacy, however, though announced in order to reduce the separate confusions assertedly implicit in conflicting state involvement in share transactions, inay be too high a price to pay for that policy shift.

I hope the foregoing review of the place of state corporation law in its federal setting, drawing upon a wider range of constitutional doctrimes and policies than that used in the current debate, justifies a inoderate reading of CTS"s "state of incorporation" passages. ${ }^{79}$ The entire discussion in CTS bears on one particular type of state regulation-that of takeover bids-not on state corporation law generally. The Court's equation of takeover legislation with traditional subjects of corporation law is not for the purpose of making the latter as "sensitive" to commerce clause scrutiny as the former, but to demonstrate that the former is as legitinate a function of state law as the latter. Indeed, most of the subsequent discussion in the case speaks of the inevitability of having some principles of state corporation law involved even in a stock-transacting situation, principles which at least minimally do impact on the

79. See supra note 26. See also Tzouganatos, Private International Law as a Means to Control the Multinational Enterprise, 19 VAND. J. TRANSNAT'L L. 477 (1986) (using private international principles to demonstrate the legitimacy of true "home state" law application over that of state of incorporation and noting that "if a corporation overemphasizes the need for certainty, it always has the alternative of incorporating at home." Id. at 513.). 
interstate commerce implicit in stock market tradimg. The less directly a state law impacts on thiat stock market trading institution, lowever, the less sensitive the commerce clause scrutiny need be. The multiplicity even of potentially inconsistent state laws, and the degree of mfringement by any (even a single) state's law on an instrumentality of commerce, tlius are related.

The Court's bow to the state of imcorporation as the primus inter pares is in a sense only a surrogate for the state's imterest in shareholders and in other local objects of its police power. While the opimion is careful not to equate the state of incorporation with the residence of the sliarellolders the state is protecting with its $1 a w,{ }^{80}$ it does indicate that shareholder welfare is a major touclistone of any state's corporation law rules, even those of tlie state of imcorporation. As a result, the more resident sliareliolders and otlier local interests another state can cover with its rules, the less likely it is that its law will liave to take second place to that of the state of incorporation. To take the pure case: if a Delaware corporation can point to no shareholder within Delaware, and if California is the residence of all its shareholders, the Court, faced with an absolute dilemma (e.g., inconsistent rules) may well give primacy to the shareliolder state.

The foregoing analysis lias discussed the "Delawarization" of state statutory responses to the takeover phenomenon, implicit in CTS"s embedding of the state-of-incorporation version of the internal affairs doctrine in the Constitution via the dorinant cominerce clause. It has attempted to rebuff any suggestion that this "Delawarization" extends also to other substantive areas of corporation law. It now is appropriate to speculate about the consequences of Justice Powell's approach specifically to state takeover statutes that differ substantively or jurisdictionally from the Indiana regime. To introduce this effort, a brief gaming scenario, more political than legal, needs to be developed.

Financial planners and players who engage in takeover activity are likely to find ways around at least some versions of the Indiana type of statute. A takeover bid contingent on the offeror's success in regaining full voting rights at the subsequent meeting of the remaining shareholders is one such way. Care would have to be taken to stay within the sixty-day limit implied in CTS's ungenerous stay of the Williams Act preemption threat, but this is technically feasible. The Indiana statute itself may even permit the tender offer to be contingent upon the concurrent statement of the individual putative seller's intention to vote favorably, depending on low well the proxy phrasing avoids the disqualifying power of the acquiror "to exercise or direct the exercise of the [acquired

80. 55 U.S.L.W. at $4484 \mathrm{n} .12$ (noting that the rules of the state of incorporation may affect nonresident as well as resident shareholders). 
shares'] voting power."81

More significantly, determined bidders inay inake their offer contingent on the inanagement's successful effort to lift the disfranchising bar, whether by simply exhorting management to encourage shoreholders to vote therefor at the upcoming meeting or by pressuring mangement to use its residual but powerful authority to "help" that result along-either by using its retained exeinptive power or by granting asset or other lockup options. These maneuvers, of course, are simply variants of bidders' warnings to target management that resistance to a good abovemarket bid without resort to a better alternative is a breach of management's special duty of loyalty to its (majority?) shareholders. ${ }^{82}$

81. Justice Powell implies that all shares (other than those already owned by the bidder and by inside directors and officers of the target) vote on the decision whether to invest the control shares acquired or to be acquired by the bidder with full voting rights. At least by indirection this is made a condition of rejecting a Williams Act preemption (id. at 4481-82). This separate vote is carried out in two separate "group" votes. The first seems traditional and involves the speeially stated right of preferred stock to vote separately on inatters having class-speeific effects on that stock-not a cominon problem in the case of first-stage takeover bids. The scond group vote repeats that structure but disenfranchises the mentioned "bidder-held" and "incumbent control group-held" shares. See IND. CODE § 23-1-42-9(b) (Supp. 1986). "Control" is functionally defined in subsection 3 as the right to "exercise or direet the exercise of the voting power of the corporation [sic?]" over those shares.

Prersumably, therefore, direct acquisition of a control bloc before the record date for the spearately demanded shareholders' meeting disqualifies them; acquisition after the record date, which Justice Powell assumes will be the normal case (id. at 4479 n.2), of course carries no direct voting right. If in the latter case the acquiror conditions its bid on obtaining the proxy of the tendering seller, it would then at least indirectly "exercise" the forbidden voting right. It might be possible to craft the proxy so that it specifies the giver's specified "yea" vote and thus slips by the "direction" block; but a tender solicitation contingent on that proxy submission still wonld violate the prohibition. Of course, this does not bar arbitrageurs from voting their shares at the meeting, if they are not themselves above the minimum "control" level.

One result of this structure is to cause the potential bidder simply to announce its intention to bid and thereby to trigger the plebiscite immediately. That reading is confirmed by subsection 6 , which defines an "acquiring person" (eligible to demand the uneeting call) as one "who proposes to make or has made a control share acquisition." At this point the only shares barred from voting on the "vote reinstatement" proposal are those owned by management as defined; a majority vote of the other shareholders then would suffice to clear the way for the control acquisition bid. In short, so long as the bidder asks for and succeeds in attracting the interet of $51 \%$ (in value) of the outside shareholders for its proposal, it has passed over this hurdle.

At that point the non-consenting shareholders, however, presumably even those excluded from voting, have a "dissenter's" appraisal right under subsection 11, for which the previous actual or proposed bid price serves as a "fair value" floor. This, of course, converts a first-stage partial tender offer into an obligatory total one.

Compare HAw. REv. STAT. $\$ 415-172$ (Supp. 1986), which permits the bidder to solicit proxies so long as this is done separately from and later than the solicited tender, yet also no sooner than 30 days before the vote-reinstatement meeting. Of course, the bidder can make its tender offer contingent upon a positive result, under either statute. Both approaches finesse the "prisoner's dilemma" effect of a potentially coercive tender. See Bebchuk, Toward Undistorted Choice and Equal Treatment in Corporate Takeovers, 98 HARV. L. REv. 1693 (1985). But the Hawaii approach may give the bidder inore transactional fiexibility.

82. See Oesterle, The Negotiation Model of Tender Offer Defenses and the Delaware Supreme Court, 72 CoRnell L. Rev. 117 (1986). 
The earlier decision of a majority to put this voting barrier in place may provide an uncertain immunity from sucli a cliarge; but at the least, directors willing to take that approach probably would reniain free to do so to whatever degree tliey enjoyed that freedom in prerestriction days. In sliort, these early second-generation statutes may provide little niore freedom of movement for management and little more stability of expectations for "loyalist" shareholders than do the transactionally oriented equity-dilution (poison pill) and asset-dilution (crown jewel option) devices that Delaware and perliaps some other states have enipowered directors to emplace (but not necessarily employ) with or without sliareholder authorization. ${ }^{83}$

The searcli for firmer antitakeover devices, therefore, probably is not over. From the substantive perspective, that may reawaken the Williams Act preemption rebuffed in Edgar v. MITE but now embraced-no matter that it was found factually imapplicable-in CTS. That, in turn, may revive interest in the doctrinal "contractarian" distinction between a general enabling law not deemed state action and a specific statute. ${ }^{84}$

This search lias iniplications also for the jurisdictional problem that has been the main focus of this Essay, tliough they are implications difficult to tease out at this time. If it can be assumed that most states now are interested in enacting a state takeover statute, ${ }^{85}$ and tliat Delaware is in that group, ${ }^{86}$ its version will liave factual pride of place because of the implications of the CTS commerce clause approacli, whitever that version's fate may be under the preemption analysis of the case. That Delaware will opt for the arbitrageur ratlier than tlie board of directors and tlus, by doing nothing, condemn all states to do nothing, is an unlikely prospect. Delaware, lowever, may opt for a minimalist version of a state statute that is less aggressive thin the niaxinum allowable under the preemption threat; or it may clioose to stay witl its judicial version of its current general enabling law structure, letting directors rather than sliareliolders decide whether to enplace structural (secondvote) or transactional (poison pill, asset option) controls on hostile takeovers. From the perspective of incumbent directors, lowever, the gain from any contractarian exemption from otlerwise applicable preemption invalidation may be outweighed by the cost of the Delaware courts' retrospective and in terrorem review of actual showstopping rejections of

83. Moran v. Household Int'l, Inc., 500 A.2d 1346 (Del. 1985); see Buxbaum, The Internal Division of Powers in Corporate Governance, 73 CALIF. L. REv. 1671 (1985).

84. See supra text accompanying note 14.

85. See Romano, supra note 6 , at 138.

86. See Ebb in Takeovers Foreseen, N.Y. Times, Apr. 23, 1987, at 27, col. 3 (speculation about Delaware's and other states' plans); $c f$. Romano, supra note 6, at 189 (political-economic speculation about Delaware's situation in this context). 
takeover bids. ${ }^{87}$ On the other hand, to the degree a "collective meeting" statute takes agenda control of defensive strategies away from the board of directors, casts doubt upon previously accepted other managerial defensive strategies, and allows potential bidders to force targets into play more easily than before, it reduces the desirability of any legislative change from a managerial perspective. ${ }^{88}$

If the resolution of these (and, undoubtedly, other) considerations motivates Delaware to adopt a middle-of-the-road takeover control statute, especially one that insists on shareholder involvement in the decision to emplace the particular structure chosen, this may dampen pressure from other states for substantively more aggressive statutes. If a substantial disparity of policy preferences develops, however, and if the internalaffairs primacy of Delaware as the preferred place of incorporation were to grant it, under CTS, a kind of squatter sovereignty within the federal system-federal corporation law-would be the likely result. ${ }^{89}$

87. The combination of Revlon v. MacAndrews \& Forbes Holdings, Inc., 506 A.2d 173 (Del. 1986) and Smith v. Van Gorkom, 488 A.2d 858 (Del. 1985) makes for a potent dose of operational uncertainty.

88. For example, once a contingent bid has been made and the call for a shareholders' meeting inexorably triggered, the incumbent board would find it difficult to justify exercise of poison pill, asset option, and related mechanisms under even Moran's fiduciary duty rationale, let alone Revlon's. Nor could it offer management alternatives like buyouts or internal recapitalizations if they were so conditioned as to leave shareholders with only a Hobson's choice between the two bids; see AC Aquisitions Corp. v. Anderson, Clayton \& Co., 519 A.2d 103 (Del. Ch. 1986).

89. While the "federal corporation law" issue is an old one, Karjala, Federalism, Full Disclosure, and the National Markets in the Interpretation of the Federal Securities Law, $80 \mathrm{Nw}$. U.L. REV. 1473, 1485, 1490 (1986) already draws this conclusion for reasons related to the dilemma discussed in the foregoing text. 
